\title{
Australian governments' spending on preventing and responding to drug abuse should target the main sources of drug-related harm and the most cost-effective interventions
}

\author{
DAVID MCDONALD
}

National Centre for Epidemiology and Population Health, The Australian National University, Canberra, ACT, Australia

\begin{abstract}
A notable feature of Australian drug policy is the limited public and professional attention given to the financial costs of drug abuse and to the levels and patterns of government expenditures incurred in preventing and responding to this. Since 1991, Collins and Lapsley have published scholarly reports documenting the social costs of drug abuse in Australia and their reports also contain estimates of governments' drug budgets: revenue and expenditures. They show that, in 2004-2005, Australian governments expended at least $\$ 5288$ million on drug abuse, with $50 \%$ of the expenditure directed to preventing and dealing with alcohol-related problems, $45 \%$ to illicit drugs and just 5\% to tobacco. Some 60\% of the expenditure was directed at drug crime and 37\% at health interventions. This pattern of resource allocation does not adequately reflect an evidence-informed policy orientation in that it largely fails to focus on the drug types that are the sources of the most harm (tobacco and alcohol rather than illicit drugs), and the sectors for which we have the strongest evidence of the cost-effectiveness of the available interventions (treatment and harm reduction rather than legislation and law enforcement). The 2010-2014 phase of Australia's National Drug Strategy should include incremental changes to the resource allocation mix, and not simply maintain the historical resource allocation formulae. [McDonald $\mathrm{D}$. Australian governments' spending on preventing and responding to drug abuse should target the main sources of drug-related harm and the most cost-effective interventions. Drug Alcohol Rev 2011;30;96-100]
\end{abstract}

Key words: cost analysis, expenditure, government, health, law enforcement.

A notable feature of Australian drug policy is the limited public attention that is given to the financial costs involved, including expenditures incurred by governments, in preventing and responding to drug abuse. Related matters that one might expect to be of broad public interest include comparing the levels of expenditure made by Australian governments in this area with the levels of revenues that governments obtain from taxes on tobacco products and alcoholic beverages. While academic economists have paid attention to this issue [e.g. participants in the Public Expenditure research stream of the European Monitoring Centre for Drugs and Drug Addiction (http://www.emcdda.
europa.eu/html.cfm/index1357EN.html) ], the topic has never been systematically addressed in National Drug Strategy policy documents, such as the current National Drug Strategy; Australia's integrated framework 2004-2009 [1], nor in the various evaluations of the National Drug Strategy prior to the most recent one [2].

This is curious on two counts. The first is that, when the National Campaign Against Drug Abuse was established in 1985, its central component was new money and a new funding formula for addressing drug abuse at the National, State and Territory levels [3]. The second is that, since 1991, we have had available

David McDonald BA, DipSocWk, MA, GradDipPoplnHlth, Consultant in Social Research \& Evaluation and Visiting Fellow. Correspondence to Mr David McDonald, 1004 Norton Road, Wamboin, NSW 2620, Australia. Tel: +61 26238 3706; Fax: +61 29475 4274; E-mail: david.mcdonald@socialresearch.com.au

Received 17 December 2008; accepted for publication 17 March 2010. 
detailed information on the social costs of drug abuse in Australia and, accompanying that, estimates of government expenditures in this area. These are the reports of studies undertaken by Collins and Lapsley [4-7]. In each case, these studies have been commissioned and published under the auspices of the National Drug Strategy. The fourth and most recent in the series, published in April 2008, is The Cost of Tobacco, Alcohol and Illicit Drug Abuse to Australian Society in 2004/05 [7]. This Brief Communication presents a secondary analysis of the data presented in various tables found in that report and draws conclusions regarding the targeting of Australia's drug expenditures. It is important to note that this Commentary focuses on Collins and Lapsley's estimates of government expenditures on addressing drugs and drug-related harm, rather than on the overall social costs which is the main focus of their publications cited here.

The Cost of Tobacco, Alcohol and Illicit Drug Abuse to Australian Society in 2004/05 [7] is a sophisticated analysis using an up-to-date set of methodologies and data sources. While the authors' primary focus was to estimate the social costs of drug abuse in Australia, it is also possible to explicate, from the information they provide, expenditures on drug abuse by the Commonwealth and the States and Territories separately, expenditures on the different categories of drugs of abuse and expenditures in different intervention sectors, particularly health and criminal justice. These expenditures can be compared with government revenues from alcohol and tobacco products and with the total social costs of drug abuse.

Collins and Lapsley's report contains a number of caveats, particularly regarding missing data and methodological challenges. Those caveats are especially important in the area of drug budgets as they indicate that it has not been possible for the authors to estimate government expenditures in some important (though low expenditure) areas, including drug research and drug education. Other researchers have attempted to fill some of those gaps, including the Drug Policy Modelling Program team [8]. Scholars have pointed to the limitations of Collins and Lapsley's 'cost-of-illness' methodology, suggesting how some of its limitations can be overcome [9].

\section{Commonwealth, State and Territory governments' expenditures on drug abuse, 2004-2005}

Collins and Lapsley provided estimates of expenditures by governments on alcohol, tobacco and illicit drugs; on health interventions, crime interventions and addressing road crashes and fires; and by the Commonwealth Government separately from the State and Territory governments. Tables 1 and 2 show the estimated expenditure by the Commonwealth, State and Territory governments combined on drug abuse in the years 2004-2005. It totalled $\$ 5288$ million.

Looking first at expenditures on the various types of drugs (Table 1), it will be noted that $50 \%$ of the expenditures were directed to preventing and dealing with alcohol-related problems, $45 \%$ to illicit drugs and just $5 \%$ to tobacco. This can be contrasted with the health impacts of the various classes of drugs: $65 \%$ of the Australian burden of disease from substance abuse in 2003 was accounted for by the use of tobacco, compared with $19 \%$ linked to alcohol use and $16 \%$ to the use of illicit drugs [10]. The policy implications of this mismatch between the sources of harm and the categories of drugs which draw the public dollar are stark: tobacco deserves far greater attention than it currently receives.

Table 1. Estimated Commonwealth, State E Territory government expenditures on drugs, 2004-2005, by type of drug (\$ million)

\begin{tabular}{|c|c|c|c|c|}
\hline \multicolumn{5}{|l|}{ Health } \\
\hline$\%$ & 79 & 13 & 8 & 100 \\
\hline \multicolumn{5}{|l|}{ Crime } \\
\hline$\$ \mathrm{~m}$ & 975 & 0 & 2212 & 3187 \\
\hline$\$ \mathrm{~m}$ & 106 & 10 & 21 & 138 \\
\hline$\%$ & 77 & 7 & 15 & 100 \\
\hline \multicolumn{5}{|l|}{ Total } \\
\hline$\$ \mathrm{~m}$ & 2636 & 260 & 2392 & 5288 \\
\hline$\%$ & 50 & 5 & 45 & 100 \\
\hline
\end{tabular}

${ }^{a}$ Not elsewhere included. Source: [7], pp. $68-74$, and author's calculations. 
Table 2. Estimated Commonwealth, State $\mathcal{E}$ Territory government expenditures on drugs, 2004-2005, by intervention sector (\$ million)

\begin{tabular}{|c|c|c|c|c|c|c|c|c|}
\hline & \multicolumn{2}{|c|}{ Alcohol } & \multicolumn{2}{|c|}{ Tobacco } & \multicolumn{2}{|c|}{ Illicit drugs } & \multicolumn{2}{|c|}{ Total } \\
\hline & $\$ \mathrm{~m}$ & $\%$ & $\$ \mathrm{~m}$ & $\%$ & $\$ \mathrm{~m}$ & $\%$ & $\$ \mathrm{~m}$ & $\%$ \\
\hline Health & 1555 & 59 & 249 & 96 & 159 & 7 & 1964 & 37 \\
\hline Crime & 975 & 37 & 0 & 0 & 2212 & 92 & 3187 & 60 \\
\hline Road crashes \& fires, n.e.i. ${ }^{a}$ & 106 & 4 & 10 & 4 & 21 & 1 & 138 & 3 \\
\hline
\end{tabular}

${ }^{a}$ Not elsewhere included. Source: [7], pp. 68-74, and author's calculations.

The second finding, emerging from Table 2, is concerned with the intervention sectors that attract public funds. Sixty per cent of expenditures are directed to preventing and responding to crime, compared with $37 \%$ allocated in the health sector. The issue for policy-makers is that a substantial body of research evidence exists demonstrating the effectiveness, and cost-effectiveness, of drug-related interventions in the health sector (particularly through treatment and harm reduction), and how these are substantially higher than in the criminal justice sector [11]. For example, Australian research has shown that '. . f for an average heroin user the cost of averting a year of heroin use is approximately AUD $\$ 5000$ for pharmacotherapy maintenance, AUD $\$ 11000$ for residential rehabilitation and AUD\$52 000 for prison' [12]. An impediment to making resource allocation decisions is the paucity of research into the outcomes of legislative and law enforcement interventions relating to drugs [13].

The total expenditure of $\$ 5288$ million on drug abuse in 2004-2005 by the Commonwealth, State and Territory governments combined can be compared with Collins and Lapsley's estimates of the social costs of drug abuse in Australia which totalled (in net terms) $\$ 55173$ million of which $\$ 30290$ million were tangible costs. Of the five main categories of tangible costs, $65 \%$ were related to lost production in homes and workplaces, $19 \%$ to crime, $7 \%$ to health (net costs) and $8 \%$ to road crashes. Again, this shows a mismatch between the sources of costs and where public funds are expended.

The estimate of Government expenditure on drug abuse of $\$ 5288$ million in $2004-2005$ is just $10 \%$ of the estimated social costs of drug abuse in Australia. This is broadly consistent with the observation, derived from an international overview, that 'In the countries for which results are already available, the [government] drug budget on average represents only about $5 \%$ of the social costs of drugs use' [14].

\section{Government revenue from drugs}

The impacts of alcohol and tobacco on government revenues are substantial. Here we deal with gross government revenue, for example from excise taxes and customs duties, rather than net revenue which also takes into account revenue forgone. As Collins and Lapsley explain, 'Consumption of alcohol had a positive effect on the federal budget but negative effects on state budgets, while tobacco consumption had positive effects on both federal and state budgets. Since illicit drugs yield no tax revenue directly (while causing a reduction in general tax revenues) illicit drug abuse had a negative effect upon both Federal and State budgets' [7]. As shown in Table 3, total government revenue from tobacco and alcohol in 2004-2005 was $\$ 11788$ million, with tobacco products providing $57 \%$ of the total and alcoholic beverages $43 \%$. The total expenditure on preventing and responding to drug abuse of all drugs by governments in the year, $\$ 5288$ million, was less than half (45\%) the level of revenue. The mismatch is highlighted with respect to tobacco: revenue of $\$ 6675$ million and expenditure of $\$ 260$ million.

\section{Conclusions}

Despite challenging methodological and data availability issues, Collins and Lapsley's research has provided valuable information on the social costs of drug abuse in Australia and government expenditures on, and revenue from, drugs. Although the social cost estimates are frequently quoted, it is rare to see any systematic policy use of them, nor of the other information provided in Collins and Lapsley's research publications. (An exception is the evaluation of the 2004-2009 phase of the National Drug Strategy [2].) Perhaps this reflects the presentation of the findings. On the other hand, perhaps it reflects reluctance, on the part of decision makers, such as the members of the Ministerial Council on Drug Strategy, the peak decision-making body for 
Table 3. Estimated Commonwealth, State E Territory government revenue from drugs, 2004-2005 (\$ million)

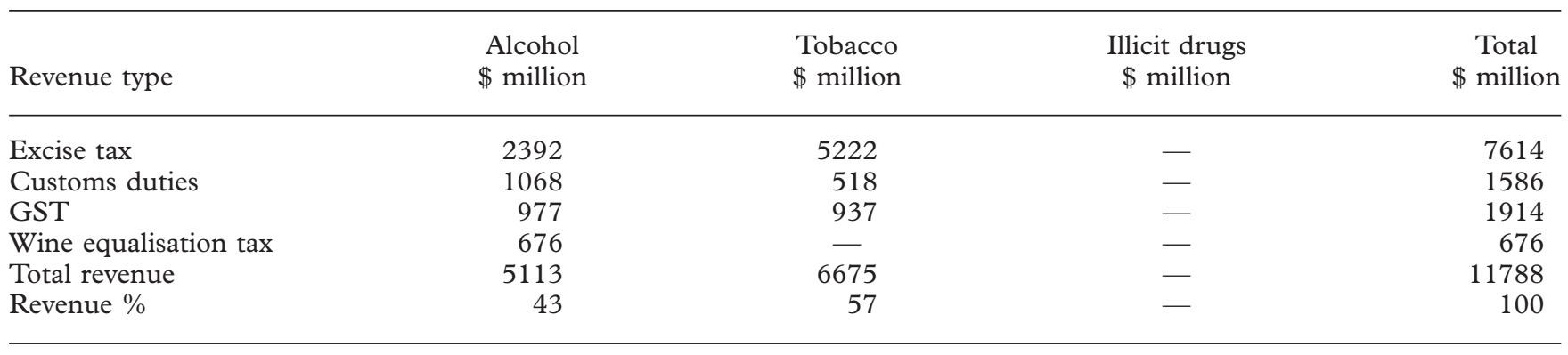

Source: [7], pp. 68-74, and author's calculations. GST, the Commonwealth Government's 10\% Goods and Services Tax.

the Australian National Drug Strategy, to engage with the implications of the data, namely addressing the balance of resource allocation to dealing with the different drug types and the different intervention sectors.

The word 'balance', in discussing resource allocation, is problematic. For some observers, it means approaching equality in the quantum of funds allocated to the various drugs and implementation sectors. To others, it means aligning allocations to the relative burdens that the different sources of drug-related harm impose on society. To yet others, it means allocating resources in accordance with existing evidence for cost-effectiveness in attaining what are often unclear goals. This Commentary argues that all three approaches have merit and should be part of the decision-making frameworks of governments. The 'balance' concept also draws attention to the importance of balancing, in systematic policy analyses, the diverse sources of evidence and influence that shape policy decisions, with researchbased evidence being only one of these, and frequently not the most powerful [15].

One of the objectives of Australia's National Drug Strategy is to 'promote evidence-informed practice' [1]. I suggest that promoting evidence-informed policy is as important as promoting evidence-informed practice. Spending public money is the most powerful of the policy instruments that governments have available to address drug abuse, but the resource allocation policies across drug types and intervention sectors do not sufficiently demonstrate a rational, evidenceinformed approach. This is because the pattern of spending fails to give precedence to the drug types that are the source of most harm to Australian society, and to the sectors for which we have strongest evidence of the effectiveness and cost-effectiveness of the available interventions. A more fully evidenceinformed approach to Australian drug policy would include a commitment and a strategy to move financial resources in these directions. Rational, evidenceinformed policy activity at both the Commonwealth and State/Territory government levels would result in far higher expenditures on tobacco, and on treatment addressing all drugs, compared with expenditures on criminal justice interventions on the currently illegal drugs. Spending $60 \%$ of the drug budget on preventing and responding to drug-related crime is not a rational policy. The current initiative to develop a new National Drug Strategy for Australia provides opportunities for incremental movement towards a more evidence-informed set of resource allocation decisions on drugs.

\section{References}

[1] Ministerial Council on Drug Strategy. The National Drug Strategy; Australia's integrated framework 2004-2009. Canberra: Dept of Health and Ageing, 2004.

[2] Siggins Miller, Miller M-E, Siggins I, et al. Evaluation and monitoring of the National Drug Strategy 2004-2009: final report. Canberra: Ministerial Council on Drug Strategy, 2009.

[3] Special premiers' conference on drugs, Canberra, 2 April 1985. Communiqué. Canberra.

[4] Collins DJ, Lapsley HM. Estimating the economic costs of drug abuse in Australia. National Campaign Against Drug Abuse Monograph Series no. 15. Canberra: Dept of Community Services and Health, 1991.

[5] Collins DJ, Lapsley HM. The social costs of drug abuse in Australia in 1988 and 1992. National Drug Strategy Monograph Series no. 30. Canberra: AGPS, 1996.

[6] Collins DJ, Lapsley HM. Counting the cost: estimates of the social costs of drug abuse in Australia in 1998-9. National Drug Strategy Monograph Series no. 49. Canberra: Dept of Health and Ageing, 2002.

[7] Collins DJ, Lapsley HM. The costs of tobacco, alcohol and illicit drug abuse to Australian society in 2004/05. National Drug Strategy Monograph Series no. 64. Canberra: Dept of Health and Ageing, 2008. Available at: http:// www.nationaldrugstrategy.gov.au/internet/drugstrategy/ publishing.nsf/Content/mono64 (accessed 17 November 2008).

[8] Moore TJ. The size and mix of government spending on illicit drug policy in Australia. Drug Alcohol Rev 2008;27:404-13.

[9] Moore TJ, Caulkins JP. How cost-of-illness studies can be made more useful for illicit drug policy analysis. Appl Health Econ Health Policy 2006;5:75-85. 
[10] Begg S, Vos T, Barker B, Stevenson C, Stanley L, Lopez AD. The burden of disease and injury in Australia 2003. (AIHW cat. No. PHE 82). Canberra: Australian Institute of Health, 2007.

[11] Boyum D, Reuter P. An analytic assessment of U.S. drug policy. Washington, D.C: AEI Press, 2005.

[12] Moore TJ, Ritter A, Caulkins JP. The costs and consequences of three policy options for reducing heroin dependency. Drug Alcohol Rev 2007;26:369-78.

[13] Mazerolle L, Soole D, Rombouts S. Drug law enforcement: a review of the evaluation literature. Police Quarterly 2007; $10: 115-53$
[14] Single E, Collins D, Easton B, et al. International guidelines for estimating the costs of substance abuse, 2nd edn. Geneva: World Health Organization, 2003.

[15] Banks G. Evidence-based policy making: what is it and how do we get it? In: Wanna J, ed. Critical reflections on Australian public policy: selected essays. Acton, A.C.T.: ANU E Press, 2009:107-29. 